Edukids 15 (2), 2018

EDUKIDS: Jurnal Pertumbuhan, Perkembangan, dan Pendidikan Anak Usia Dini

Jln. Dr. Setiabudhi No. 229 Kota Bandung 40154. e-mail: edukid@upi.edu website: http://ejournal.upi.edu/index.php/edukid

\title{
PROFIL KREATIVITAS GURU DALAM MENGEMBANGKAN MEDIA PEMBELAJARAN
}

(Studi Kasus pada Guru di Taman Kanak-Kanak Sekolah Alam Bandung)

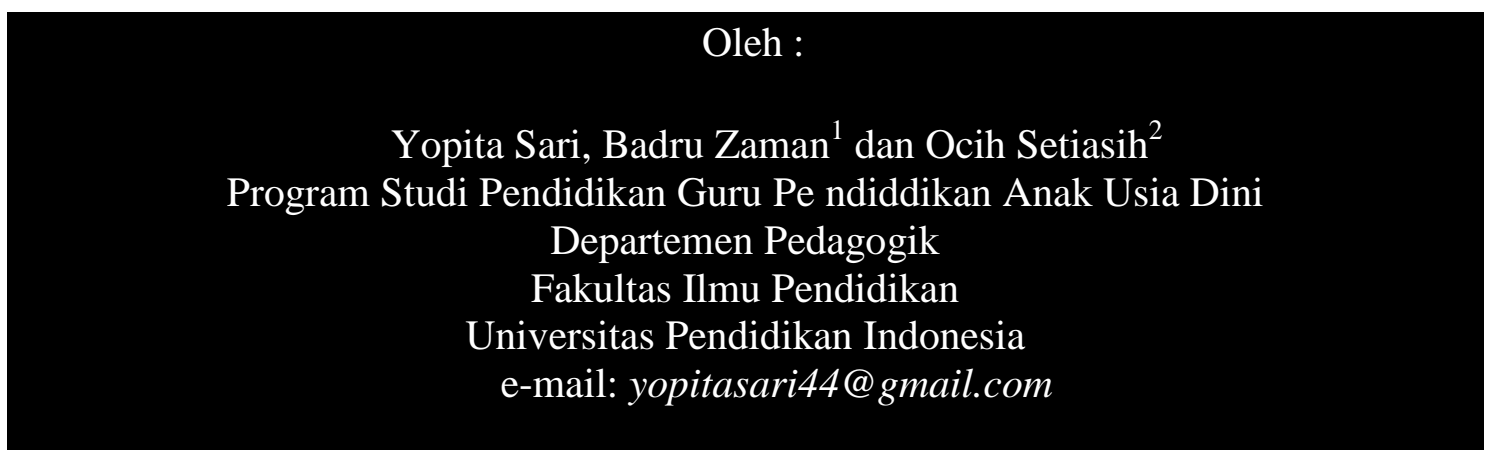

Abstrak: Penelitian ini dilatarbelakangi oleh pentingnya kreativitas dalam profesi guru, salah satunya dalam mengembangkan media pembelajaran. Peneliti memilih TK Sekolah Alam Bandung untuk dijadikan sebagai tempat penelitian. Tujuan penelitian ini adalah untuk mengetahui gambaran kreativitas guru dalam mengembangkan media pembelajaran di TK Sekolah Alam Bandung. Penelitian yang dilakukan menggunakan pendekatan kualitatif dengan metode penelitian studi kasus. Teknik pengumpulan data dilakukan dengan cara observasi dan wawancara kepada empat orang guru. kemudian hasil penelitian dianalisa dengan menggunakan teori tematik. Dalam penelitian ini gambaran kreativitas guru dalam mengembangkan media pembelajaran dilihat dari segi produk kreatif berupa media pembelajaran. media kreatif dapat dinilai dengan tiga aspek yaitu kebaruan, resolusi, serta elaborasi dan sintesis. Hasil temuan penelitian menunjukkan bahwa: pertama, dilihat dari kebaruan media, media yang dibuat guru di TK Sekolah Alam Bandung memiliki ciri kebaruan, seperti 60-70\% menggunakan bahan lingkungan sekitar. Kedua, dilihat dari aspek resolusi, media di TK Sekolah Alam Bandung tidak hanya dirancang untuk memudahkan guru akan tetapi disesuaikan dengan kebutuhan anak juga. Ketiga, dilihat dari aspek elaborasi dan sintesis, media yang dibuat guru di TK Sekolah Alam Bandung sebagian besar tampil sederhana tapi dibalik kesederhanaannya media memiliki banyak manfaat.

Kata Kunci : Profil Kreativitas Guru, Media Pembelajaran

\footnotetext{
${ }^{1}$ Penulis Penanggung Jawab

${ }^{2}$ Penulis Penanggung Jawab
} 


\begin{abstract}
This research is motivated by the importance of creativity in the teaching profession, one of them in developing learning media. The researcher chose the TK Sekolah Alam Bandung to be used as a place of research. The purpose of this study is to describe the teacher's creativity in developing learning media in TK Sekolah Alam Bandung. Research conducted using a qualitative approach with case study research methods. Data collection techniques were carried out by observation and interviews with four teachers. Then the results of the study were analyzed using thematic theory. In this study the picture creativity of teachers in developing instructional media in terms of creative products in the form of instructional media. creative media can be assessed with three aspects, namely novelty, resolution, and elaboration and synthesis. The results of the research show that: first, judging from the novelty of the media, the media created by the teachers at TK Sekolah Alam Bandung has a novelty, such as $60-70 \%$ using environmental materials. Second, judging from the aspect of resolution, the media at TK Sekolah Alam Bandung were not only designed to facilitate teachers but also adapted to the needs of children. Third, judging from the aspects of elaboration and synthesis, the media created by teachers at TK Sekolah Alam Bandung mostly appear simple but behind the simplicity of the media has many benefits.
\end{abstract}

\title{
Keywords: Profile of Teacher Creativity, Learning Media
}

\section{PENDAHULUAN}

Kreativitas sangat penting untuk keberlangsungan hidup di masa depan. Dimana dengan kreativitas hidup bisa lebih baik, karena kreativitas bisa menjadikan sesuatu yang sulit menjadi lebih mudah. Pentingnya kreativitas diantaranya yaitu untuk mempersiapkan generasi masa depan, supaya dapat "bertahan hidup" (Parkhurst dalam Shaheen, 2010), serta kreativitas penting untuk mengaktualisasikan diri (Maslow dalam Mariyana, 2008). Oleh sebab itu penting bagi seorang individu untuk mengembangkan kemampuan berfikir agar hidupnya dapat lebih kreatif, karena dengan hidup kreatif maka seorang individu akan lebih produktif dan dapat mempersiapkan masa depan yang lebih baik.

Kreativitas penting dalam profesi guru, salah satunya yaitu dalam mengembangkan media pembelajaran. Media pembelajaran merupakan alat yang bisa digunakan untuk membuat pembelajaran lebih menarik dan dapat memudahkan komunikasi antara guru dan anak ketika belajar, sehingga dengan menghadirkan media maka guru akan terbantu agar tidak terlalu banyak menjelaskan karena dengan hadirnya media akan memudahkan anak untuk mengerti apa yang ingin guru sampaikan. Selain itu, dari beberapa hasil penelitian sampai pada kesimpulan, bahwa proses dan hasil belajar pada siswa menunjukkan perbedaan yang signifikan antara pembelajaran tanpa media dan pembelajaran menggunakan media (Mursid, 2015, hlm. 41).

Namun pada kenyataannya masih terdapat guru yang kurang kreatif khususnya dalam mengembangkan media pembelajaran, karena sampai pada saat ini masih terdapat guru yang alakadarnya ketika mengajar. Media pun jarang dihadirkan, apalagi jika guru sudah merasa kekurangan ide, guru cenderung memakai 
buku lembar kerja siswa yang monoton. Hal ini terjadi karena pengalaman yang didapatkan oleh guru masih kurang, dimana dengan pengalaman tersebut seorang guru dapat menambah kualitas kreativitasnya ke tingkat yang lebih tinggi, karena pada hakikatnya tidak ada orang yang tidak kreatif, yang menjadi pembeda adalah tinggi rendahnya tingkat kreativitas yang dimiliki oleh seseorang tersebut (Supriadi, 2001).

Di samping masih terdapat guru yang kurang termotivasi untuk lebih kreatif dalam mengembangkan media pembajaran, peneliti menemukan TK Sekolah Alam Bandung yang berada di Dago, dimana di sekolah ini guru lebih banyak memanfaatkan bahan lingkungan sekitar sebagai sumber belajar bagi peserta didiknya. Media yang dibuat oleh guru di Sekolah Alam Bandung 60-70\% terbuat dari bahan alam dan bahan bekas. Atas dasar tersebut peneliti memilih Taman Kanak-Kanak Sekolah Alam sebagai tempat penelitian.

Dalam penelitian ini peneliti akan melihat kreativitas guru di TK Sekolah Alam Bandung khusus dari produknya saja. Sebagaimana yang dikemukakan oleh Supriadi (2001, hlm.14) bahwa, "Dimensi kepribadian dari kreativitas biasanya diteliti dalam kaitan dengan kriteria lain yang lebih eksplisit, yaitu produk kreatif." Terapat pula penelitian terdahulu tentang analisis suatu produk kreatif yang dilakukan oleh Bessemer dan O'Quin (1987) di State University, dimana mereka ingin meneliti perbandingan produk mana yang lebih kreatif antara kaos bergambar Kerbau dengan kemeja Niagara Falls dengan menggunakan tiga kategori produk kreatif yaitu novelty product, resolution product, elaboration and shynthesis product. Namun dalam penelitian ini peneliti akan mencoba menilai produk yang berbeda dengan penelitian yang dilakukan Bessemer dan O'Quin yaitu yang berupa media pembelajaran yang dibuat guru Taman Kanak-Kanak di TK Sekolah Alam Bandung. Atas dasar hal tersebut, maka penulis memfokuskan kajian pada, "Profil Kreativitas Guru dalam Mengembangkan Media Pembelajaran" di TK Sekolah Alam Bandung.

Rumusan masalah dalam penelitian ini adalah sebagai berikut : Bagaimana profil kreativitas guru dalam mengembangkan media pembelajaran di Taman Kanak-kanak Sekolah Alam Bandung? Berdasarkan rumusan masalah tersebut maka pertanyaan penelitian adalah

1) Seperti apa profil kreativitas guru dalam mengembangkan media pembelajaran dilihat dari aspek novelty product di Taman Kanakkanak Sekolah Alam Bandung?

2) Seperti apa profil kreativitas guru dalam mengembangkan media pembelajaran dilihat dari aspek resolution product di Taman Kanakkanak Sekolah Alam Bandung?

3) Seperti apa profil kreativitas guru dalam mengembangkan media pembelajaran dilihat dari aspek elaboration and synthesis product di Taman Kanak-kanak Sekolah Alam Bandung?

Tujuan dalam penelitian ini adalah sebagai berikut:

1) Tujuan Umum

Mengetahui profil kreativitas guru TK dalam mengembangkan media pembelajaran di Sekolah Alam Bandung.

2) Tujuan Khusus

a. Mengetahui profil kreativitas guru dalam mengembangkan media pembelajaran dilihat dari aspek novelty product di Taman Kanakkanak Sekolah Alam Bandung. 
b. Mengetahui profil kreativitas guru dalam mengembangkan media pembelajaran dilihat dari aspek resolution product di Taman Kanak-kanak Sekolah Alam Bandung.

c. Mengetahui profil kreativitas guru dalam mengembangkan media pembelajaran dilihat dari aspek elaboration and synthesis product di Taman Kanak-kanak Sekolah Alam Bandung.

\section{METODE PENELITIAN}

Penelitian ini menggunakan pendekatan kualitatif, dengan metode studi kasus. Penelitian ini dilakukan untuk mengetahui gambaran kreativitas guru dalam mengembangkan media pembelajaran di TK Sekolah Alam Bandung. Dimana kreativitas guru dilihat dari produk kreatif berupa media pembelajaran.

Lokasi penelitian di Taman KanakKanak Sekolah Alam Bandung, yang beralamat di Jl. Cikalapa II No.4 Kp. Tanggulan Dago Pojok Kelurahan Dago Kecamatan Coblong Kota Bandung.

Partisipan yang dilibatkan dalam penelitian ini adalah guru di Taman Kanak-Kanak Sekolah Alam Bandung. Teknik pengambilan sampel dalam penelitian ini yaitu dengan menggunakan teknik purposive sampling. Maka dari itu peneliti memilih guru yang memiliki pengetahuan lebih tentang media, sehingga peneliti mengambil sampel dua guru dari kelas A dan dua guru dari kelas B, jadi jumlah partisipan sebanyak empat orang guru.

Dalam penelitian ini yang menjadi instrumen penelitian adalah peneliti sendiri. Dalam proses pengumpulan data dan menginterpretasikan data peneliti mengacu pada pedoman observasi untuk melihat media yang dibuat guru dan pedoman wawancara yang ditujukan kepada guru sebagai pembuat media.

Teknik analisis data yang digunakan dalam penelitian ini adalah thematic analisys. Jadi analisis dalam penelitian ini akan mengacu pada rumusan masalah terkait profil kreativitas guru dalam mengembangkan media pembelajaran dilihat dari kategori kebaruan produk (novelty), pemecahan (resolution), serta kerincian dan sintesis (elaboration and shyntesis) (Besemer dan Treffinger, 1981, hlm. 163).

\section{TEMUAN DAN PEMBAHASAN}

\section{Profil kreativitas guru dalam mengembangkan media pembelajaran dilihat dari aspek novelty product di Taman Kanak-kanak Sekolah Alam Bandung}

Dalam aspek kebaruan terdapat ciri khas dalam media pembelajaran yang cukup mencolok di TK Sekolah Alam Bandung yaitu bahan media yang digunakan guru lebih banyak menggunakan bahan lingkungan sekitar. Dari keseluruhan bahan yang digunakan untuk media kurang lebih 60\%-70\% guru menggunakan bahan media lingkungan sekitar. Dalam menunjang hal tersebut di TK Sekolah Alam Bandung juga terdapat tema tentang lingkungan dan daur ulang. Karena memang di sekolah alam saat ini sedang memberdayakan lingkungan. Sadiman (dalam Asmawati, 2014, hlm.36) menyatakan bahwa, "Guru perlu menyadari sepenuhnya bahwa lingkungan sangat efektif sebagai sumber dan media belajar melalui bermain bagi anak usia dini." Dengan begitu lingkungan sekitar memang bagus untuk dijadikan sebagai bahan media pembelajaran, karena banyak yang dapat 
dieksplorasi dari bahan-bahan yang ada di alam dan bahan-bahan barang bekas.
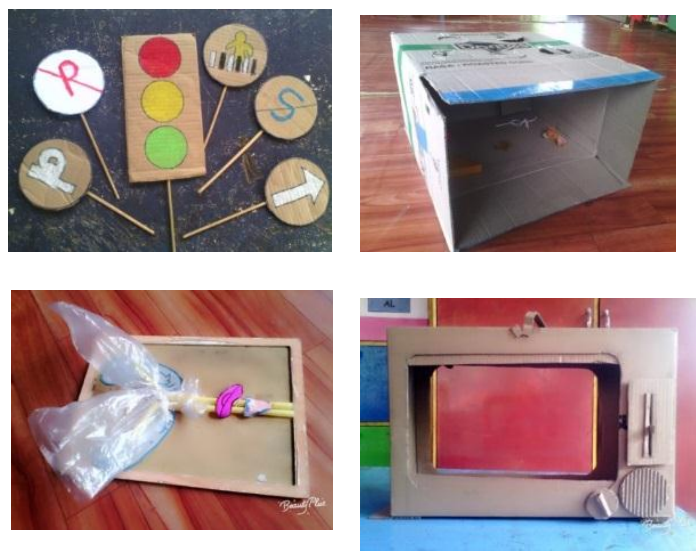

Gambar 1. Contoh media yang terbuat dari bahan lingkungan sekitar Ketika kita sudah membuat sesuatu dan hasilnya menarik, biasanya kita suka jadi terinspirasi untuk membuat lagi dengan ide baru lainnya. Begitupun hal nya dengan guru-guru di TK Sekolah Alam Bandung, mereka sering muncul ide baru setelah mereka membuat media pembelajaran. Media yang dapat memunculkan inspirasi baru bagi guru diantaranya adalah figura keluarga batu, efron, tempat sampah, dan sebagainya. Dimana media-media tersebut lebih banyak menggunakan bahan lingkungan sekitar, sehingga guru lebih banyak tersinspirasi dari bahan-bahan lingkungan sekitar, seperti batu, kardus, botol minum bekas, daun, ranting dan lain sebagainya. Proses ini dapat dikaitkan dalam proses iluminasi atau tahap pencerahan, dimana guru dapat menemukan gagasan baru (Ayan, 2002, hlm.56). Gagasan baru tersebut muncul setelah guru membuat media pembelajaran. Artinya media yang dibuat sebelumnya dapat memberikan inspirasi, sehingga media tersebut disebut media yang kreatif.
Selanjutnya dalam modifikasi media, di sekolah alam Bandung guru kadang mencontoh media yang sudah ada khususnya yang media eksperimen, dan kadang memang dimodifikasi, seperti media figura batu pada contohnya satu bentuk menggunakan satu batu, namun guru membuat satu bentuk dengan dua batu yang disatukan serta adanya tambahan variasi baju dengan menggunakan cat. Namun terdapat pula satu guru yang mengungkapkan bahwa media yang ia buat memang benar-benar sesuatu yang baru karena belum terlalu lama mengajar. Untuk idenya sendiri selain guru memang membuat media hasil ide sendiri, terkadang juga media merupakan hasil ide bersama. Hal tersebut memang wajar karena ide itu bisa hasil kerjasama, sebagaimana yang dikemukakan oleh John-Steiner (dalam Cremin, 2015, hlm. 38) bahwa, "......creativity can also be collaborative since ideas emerge from joint thinking and interaction." Jadi kreativitas itu bisa kolaboratif karena ide muncul dari pemikiran dan interaksi bersama.

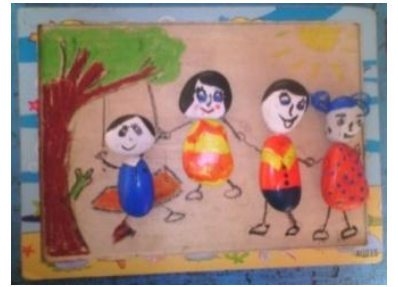

Gambar 2. Media Batu

Jika dinilai secara keseluruhan, penilaian kebaruan media yang dibuat oleh guru di TK Sekolah Alam Bandung harus dipertimbangkan dari sudut pengalaman penciptanya. Karena jika dikaitkan dengan pengalaman penciptanya media yang mereka buat merupakan sesuatu yang baru. Sebagaimana yang dikemukakan oleh Munandar (2012, hlm.43) bahwa sebagian besar pakar berpendapat bahwa "kebaruan" harus dipertimbangkan dari sudut pengalaman si pencipta. Kebaruan 
media di TK Sekolah Alam Bandung tersebut terlihat dari ciri khas media yang lebih banyak menggunakan bahan lingkungan sekitar, media dapat menumbuhkan inspirasi baru bagi guru, serta adanya modifikasi pada media yang dibuat walaupun tidak semua media menunjukkan hasil modifikasi yang signifikan.

2. Profil kreativitas guru dalam mengembangkan media pembelajaran dilihat dari aspek resolution product di Taman Kanak-kanak Sekolah Alam Bandung

Berdasarkan apa yang peneliti dapatkan dari lapangan, aspek ini cukup banyak ditemukan, dimana media yang dibuat guru di Sekolah Alam Bandung cukup memberikan resolusi bagi masalah yang ada. Pertama media yang ada di Sekolah Alam Bandung cukup sesuai dengan aturan yang sudah ditentukan bahwa media yang baik itu harus benarbenar aman untuk anak. Dari hasil wawancara serta observasi dapat diketahui dan dilihat betapa guru sangat menjaga dan mementingkan keamanan untuk anak, dan mereka lebih mempertimbangkan lagi jika medianya kurang aman bagi anak.

Kedua, media dapat memenuhi kebutuhan. Diantaranya yaitu media dapat digunakan secara klasikal, individu, dan kelompok, seperi media rambu-rambu dan lintasan jalan. Tapi kadang dalam satu hari itu tidak semua media dapat digunakan secara klasikal, individu, dan kelompok langsung dalam sehari. Kadang klasikal dan individu, kadang juga klasikal dengan kelompok, bahkan individu dan kelompok, tergantung penugasan dari gurunya. Namun jika ingin dimaksimalkan sebenarnya setiap media bisa digunakan dengan ketiga cara tersebut, hanya ketersediaan bahan dan waktu sangatlah menentukan. Selain itu untuk ukuran medianya sendiri sebenarnya standar dan tergantung kebutuhan, kadang ada yang kecil, ada yang sedang, dan kadang medianya besar. Bahkan kadang jika medianya terlalu kecil guru tetap dapat memperlihatkan dengan jelas kepada anak dengan cara guru berkeliling mendekati setiap anak sambil memperlihatkan media tersebut. jadi pemlajaran yang menarik itu tidak hanya menghadirkan media tetapi keterampilan guru dalam menggunakan media juga sangat penting.
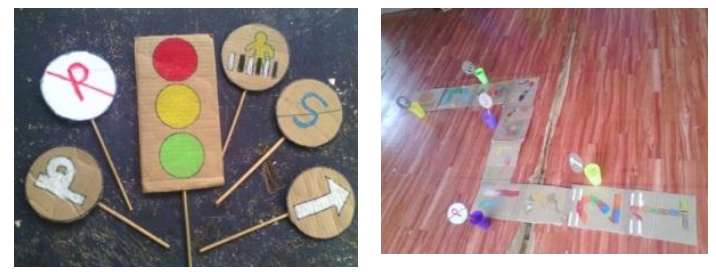

Gambar 3. Media rambu-rambu lalu lintas dan lintasan jalan

Ketiga yaitu media disesuaikan dengan kebutuhan anak. Sanjaya (2008, hlm. 226) mengemukakan bahwa selain media dipandang dari sudut kebutuhan guru media juga harus dipandang dari sudut kebutuhan siswa. Kebutuhan anak tersebut diantaranya media disesuaikan dengan usia anak, serta media dapat mengembangkan seluruh aspek perkembangan anak. Media dapat dikatakan sesuai dengan usia anak, karena guru mengadakan pemilihan media mana yang cocok dan mana yang tidak cocok bagi anak. Selain itu terdapat evaluasinya juga, apabila guru menemukan sesuatu yang tidak sesuai dengan kemampuan anak. Diluar itu setiap anak juga diberi treatment yang berbeda agar dapat berkembang sesuai usia perkembangan.

Keempat media dapat diterapkan secara praktis. Artinya media yang dibuat guru memang dapat dirasakan guru disana, bahwa dengan menggunakan 
media lebih memudahkan guru dalam menyampaikan materi. Timbal balik ke anaknya juga banyak, seperti anak lebih mudah menerima materi, apalagi untuk anak yang visual akan mudah nempel. Selain itu dalam kegiatan belajarnya pun anak lebih fokus dan tidak melamun, anak tidak mengawang-ngawang, serta anakpun lebih mudah untuk ditertibkan. Seperti ketika guru menjelaskan fungsi rambu-rambu dengan media, itu secara tidak langsung membuat anak lebih paham dan mengerti dengan menghadirkan media dimana medianya sama dengan kehidupan nyata. Dengan melakukan praktik langsung anak juga menjadi lebih paham lagi. Sehingga apa yang guru sampaikan pada hari itu masih diingat ketika ditanya lagi sebelum anak pulang. Hal tersebut menunjukkan bahwa dengan hadirnya media pembelajaran kegiatan belajar menjadi lebih berkmakna karena anak dihadapkan dengan situasi dan keadaan yang sebenarnya atau bersifat alami (Sudjana \& Rivai, 2017, hlm.208).

Kelima media memiliki nilai. Dari beberapa media yang dibuat guru terdapat media yang memang layak untuk dijual, namun ada yang memang sudah dijual, seperti media efron. Ada yang baru rencana, seperti bros. Ada juga yang memang guru baru memperkirakan, seperti media busyboard dan media figura keluarga batu. Namun dari media-media tersebut peneliti setuju baik yang baru rencana, maupun baru memperkiakan, apalagi yang sudah dijual, bahwasannya media-media tersebut memang memiliki daya tarik tersendiri. Untuk bros mungkin peneliti juga masih mengawang-ngawang bentuknya seperti apa namun untuk efron, figura keluarga batu, dan busyboard berdasarkan studi dokumentasi memang memiliki keunikan tersendiri untuk dijual. Seperti figura keluarga batu tampil dengan lucu dan warna yang menarik sehingga membuat peneliti tertarik. Untuk media busyboard juga, terlihat dalam tampilannya bahwa media tersebut terbentuk dengan keahlian yang baik dan dapat bertahan lama juga. Dengan demikian timbal baliknya adalah ada yang dapat dihasilkan dari membuat media.

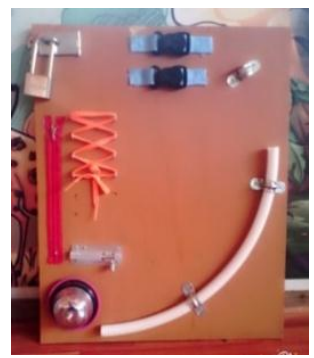

Gambar 4. Media Busyboard

3. Profil kreativitas guru dalam mengembangkan media pembelajaran dilihat dari aspek elaboration and synthesis product di Taman Kanakkanak Sekolah Alam Bandung

Dalam aspek ini media lebih dinilai dari segi tampilan, dan sejauh mana tampilan tersebut dapat memberikan pengaruh, serta sejauh mana media tersebut menunjukkan kecanggihannya. Pertama media tampil dengan komunikatif dan mudah dimengerti. Diantaranya yaitu media mudah digunakan oleh pengguna, guru mudah dalam menyampaikan pesan yang ingin disampaikan karena media tampil dengan jelas sehingga dalam waktupun lebih efektif.

Kedua media merupakan gabungan dari beberapa unsur. Namun sejauh ini media yang dibuat oleh guru di TK Sekolah Alam Bandung sebagian besar mudah dalam pembuatannya, dan guru akan merasa lebih mudah lagi jika dibantu oleh patner. Guru juga biasanya mencari referensi yang mudah, dan 
kalaupun bahan-bahannya tidak ada seperti yang dicontoh mereka akan menggunakan bahan yang ada di lingkungan sekitar. Disitulah guru terdorong untuk kreatif.

Ketiga media dapat menunjukkan keterampilan atau keahlian yang baik. Dalam menunjukkan keahlian yang baik dari suatu media, peneliti melihat dari segi ketahanan media itu sendiri. Dalam hal ketahanan media nya sendiri, tidak hanya berkaitan dengan bahannya awet atau tidak, tetapi juga faktor ruangan yang lembab sangat berpengaruh pada media, serta ketahanan media juga tergantung seberapa menarik media itu untuk anak, sehingga jika anak tertarik anak akan sering memainkan media tersebut. sampai-sampai belum ada jangka sehari, media yang dibuat guru sudah rusak. Padahal untuk beberapa media tertentu guru sudah optimis akan bertahan lama. Ternyata jika di simpan di kelas tetap saja anak mainkan.

Keempat media yang dibuat guru memang harus menarik perhatian anak sehingga anak termotivasi untuk belajar. Namun menarik menurut kita belum tentu menarik pula untuk anak, dan begitupun media yang menurut kita tidak menarik belum tentu anak tidak tertarik, bisa saja justru anak tertarik. Peneliti melihat terkadang media yang dibuat guru disajikan tanpa adanya variasi baik bentuk maupun warna, namun anak tetap tertarik dengan media tersebut dan ratarata media yang dibuat guru di TK Sekolah Alam Bandung disukai anak. Hal tersebut terbukti dengan rasa penasaran anak, dan cara anak untuk berkeinginan segera mencoba. Bahkan media yang pernah dibuat sebelumnya pun anak masih tertarik. Ada pula beberapa anak yang menunjukkan rasa tertariknya dengan membuat lagi di rumah dengan bahan media yang sama yang dipakai guru untuk membuat media. Dengan begitu berarti muncul kreativitas yang tidak lain merupakan timbal balik dari media yang guru buat.

Kelima yaitu media memiliki kesatuan organisasi atau kelengkapan. Dalam segi kesatuan organisasi atau kelengkapan, media tidak selalu memiliki keseimbangan ukuran komponen yang sesuai, karena yang terpenting bagi guru anak mengerti dan paham dengan apa yang disampaikan guru.

Keenam media memiliki nilai yang lebih dari yang tampak. Untuk warna dalam medianya sendiri kadang diserasikan, kadang juga tidak khususnya yang bahan dari lingkungan sekitar karena memang terbatas. Penggabungan beberapa warna dalam media juga sangat berguna untuk mengenalkan warna ke anak. Dari segi tampilan sebagian besar media yang di buat guru di TK Sekolah Alam Bandung terlihat sederhana, namun ketika di pakai guru untuk menjelaskan ke anak, ternyata banyak sekali aspek yang dapat dikembangan melalui media tersebut.

\section{SIMPULAN, IMPLIKASI DAN REKOMENDASI}

\section{SIMPULAN}

Secara umum gambaran media yang dibuat oleh guru di TK Sekolah Alam Bandung menunjukkan ciri produk kreatif. Hal tersebut dapat ditunjukkan dari hasil temuan dan pembahasan tentang penilaian media dengan tiga aspek produk kreatif. Pertama dari aspek novelty product, media yang dibuat guru merupakan sesuatu yang baru karena dilihat dari sudut pandang pengalaman guru. Media tersebut juga memiliki ciri khas dimana bahan yang digunakan lebih banyak menggunakan bahan lingkungan sekitar, selain itu media juga dapat 
menumbuhkan inspirasi baru bagi guru, serta adanya modifikasi pada media yang dibuat.

Kedua dilihat dari resolution product, media pembelajaran yang dibuat guru cukup memberi solusi, baik bagi guru maupun bagi anak. Hal tersebut terlihat ketika guru selalu mengutamakan keamanan media untuk anak, ukuran media selalu disesuaikan dengan kondisi anak, media dapat mengembangkan seluruh aspek perkembangan anak, media dapat memudahkan tugas guru baik dalam menjelaskan maupun dalam pengkondisian anak, media yang dibuat guru beberapa ada yang memang layak untuk dijual bahkan ada yang memang sudah dijual. Selain dari pada itu bahanbahan yang digunakan pun cukup murah dan mudah didapat.

Ketiga dilihat dari aspek elaboration and shyntesis product, media yang dibuat guru tampil komunikatif dan mudah dimengerti karena media memang dirancang sederhana. Sehingga guru tidak perlu keterampilan yang tinggi karena dengan hasil yang sederhana anak juga sudah tertarik dan dibalik kesederhanaan itu media dapat memenuhi kebutuhan anak. Sedangkan dalam ketahanan media itu sendiri dipengaruhi oleh faktor kondisi yang lembab dan seberapa menarik media tersebut buat anak. Media yang menarik akan sering dimainkan anak, selain itu anak juga jadi termotivasi untuk belajar serta dapat menginspirasi anak untuk membuat sesuatu. Dengan demikian media pembelajaran yang dibuat guru di TK Sekolah Alam Bandung memiliki ciri-ciri produk kreatif, sehingga guruguru di TK Sekolah Alam Bandung termasuk guru yang memiliki ciri-ciri guru kreatif.

\section{IMPLIKASI}

Berikut ini merupakan implikasi dari hasil penelitian :

1) Bagi peneliti

Penelitian ini dapat memberikan gambaran mengenai kreativitas guru dalam mengembangkan media pembelajaran di TK Sekolah Alam Bandung, selain itu peneliti juga banyak mendapatkan inspirasi dalam menghadirkan media yang menarik untuk anak.

2) Bagi Sekolah/Lembaga

Khususnya sekolah yang memang dekat dengan alam dan memiliki keterbatasan biaya dalam menghadirkan media. TK Sekolah Alam Bandung dapat menjadi inspirasi bagi guru-guru untuk lebih kreatif dalam membuat media pembelajaran dengan memanfaatkan bahan-bahan lingkungan sekitar.

\section{REKOMENDASI}

Berdasarkan hasil temuan di lapangan berikut ini terdapat beberapa rekomendasi yang dapat peneliti berikan kepada pihak-pihak terkait :

1) Bagi Guru

Diharapkan guru dapat membuat variasi media yang lebih beragam, sehingga dapat lebih menarik perhatian anak.

2) Bagi Sekolah

Memperbanyak kegiatan pelatihan bagi guru dalam pemahaman media pembelajaran, pembuatan media, serta dalam memanfaatkan bahan-bahan yang ada dilingkungan sekitar. Hal tersebut dilakukan agar kemampuan kreativitas guru terus berkembang.

3) Bagi Peneliti Selanjutnya

Penelitian ini membahas tentang profil kreativitas guru dalam mengembangkan media pembelajaran. Hasil penelitian ini diharapkan dapat 
menjadi referensi bagi peneliti selanjutnya. Adapun penelitian ini masih banyak kekurangan, sehingga diharapkan bagi peneliti selanjutnya untuk meneliti lebih lanjut dan lebih mendalam.

\section{DAFTAR PUSTAKA}

Asmawati, L. (2014). Perencanaan Pembelajaran PAUD. Bandung : Remaja Rosdakarya.

Ayan, J. (2002). Bengkel Kreativitas (10 Cara Menemukan Ide-Ide Pamungkas). Bandung : Kaifa.

Besemer, S.P. \& Trefinger, D.J. (1981). Analysis of Creative Products: Review and Synthesis. The Journal of Creative Behavior, 15(3), hlm. 158-178.

Besemer, S. \& O'Quin, K. (1987).Analvzing Creative Products: Refinement and Test of a Judging Instrument. The Journal of Creative Behavior, 20(2), hlm. 115-126.

Cremin, Teresa. (2015). Creative teachers and creative teaching. Hlm. 36-46.

Munandar, U.. (2012). Pengembangan Kreativitas Anak Berbakat. Jakarta: Rineka Cipta.

Mursid. (2015). Pengembangan Pembelajaran PAUD. Bandung : Remaja Rosdakarya.

Sanjaya, Wina. (2008). Perencanaan dan Desain Sistem Pembelajaran. jakarta : Kencana Prenada Media Group.

Shaheen, R. (2010). Creativity and Education. Creative Education, 1(3), hlm. 166-169.
Sudjana, N. \& Rivai, A. (2017). Media Pengajaran. Bandung : Sinar Baru Algensindo.

Supriadi, D. (2001). Kreativitas Kebudayaan dan Perkembangan Iptek. Bandung : Alfabeta.

Mariyana, Rita. 2008. Pembelajaran Kreativitas Bagi Anak Usia Dini . Jakarta : Depdiknas : DIKTI 